\title{
Feeding ecology of the fish ectoparasite Gnathia sp. (Crustacea: Isopoda) from the Great Barrier Reef, and its implications for fish cleaning behaviour
}

\author{
Alexandra S. Grutter* \\ Department of Zoology, School of Life Sciences, University of Queensland, Brisbane, Queensland 4072, Australia
}

\begin{abstract}
The feeding rate of a parasitic gnathiid isopod on fish was examined. Individual fish, Hemigymnus melapterus, were exposed to gnathiid larvae and sampled after 5, 10, 30, 60, and $240 \mathrm{~min}$. I recorded whether larvae had an engorged gut, an engorged gut containing red material, or had dropped off the fish after having completed engorgement; variation among sampling times and larval stages was analyzed using generalized linear mixed model analyses. The likelihood that larvae had an engorged gut increased with time and varied with larval stage. First stage $(<0.9 \mathrm{~mm})$ and second stage (0.9 to $1.45 \mathrm{~mm}$ ) larvae became engorged more quickly than third stage ( $>1.45 \mathrm{~mm})$ larvae. After 30 min, however, most (>93\%) larvae had an engorged gut regardless of their larval stage. The likelihood of red material in the gut of third stage larvae increased over time $(46 \%$ after $30 \mathrm{~min}, 70 \%$ after $60 \mathrm{~min}$, and $86 \%$ after $240 \mathrm{~min}$ ) while that of first and second stage larvae remained relatively low $(<27 \%)$ at all times. First and second stage larvae left the fish at a higher rate (approximately $23 \%$ after $30 \mathrm{~min}$ and $81 \%$ after $60 \mathrm{~min}$ ) than third stage larvae (3\% after $30 \mathrm{~min}$ and $26 \%$ after $60 \mathrm{~min}$ ). After $60 \mathrm{~min}$, however, the likelihood that larvae dropped off fish did not change. The variation in feeding behaviour with larval stage is likely due to variation in their diet and gut volume. The rapid feeding rate of gnathiid larvae suggests that their turnover rate on fish is high. This may explain why some fish species seek cleaner fish, which eat many gnathiid larvae, so often. By repeatedly visiting cleaner fish, gnathiids may also be removed from hosts before the parasites become fully engorged.
\end{abstract}

KEY WORDS: Parasites · Gnathiidae · Isopoda $\cdot$ Feeding behaviour $\cdot$ Labridae $\cdot$ Fish $\cdot$ Cleaner fish

\section{INTRODUCTION}

Many species of cleaner and client fish regularly engage in fish cleaning behaviour, where cleaner fish remove ectoparasites from their so called clients. For example, in the Indo-Pacific the cleaner wrasse Labroides dimidiatus cleans hundreds of fish species (Kuwamura 1976, Grutter \& Poulin 1998a, Bansemer et al. 2002) with many of these species cleaned on a daily basis and individuals of some species cleaned, on average, 144 times per day (Grutter 1995a). Examples elsewhere include Hawaii (Randall 1958, Losey 1972), the Caribbean (Wicksten 1998, Arnal et al. 2000), California (Limbaugh 1955, Hobson 1971), and the Mediterranean (Arnal \& Morand 2001).

Larval gnathiid isopods are among the parasites that are most commonly removed by cleaner fishes (re- viewed by Grutter 2002). In addition to the above locations, they have also been recorded in the diet of cleaner fishes from Portugal, Brazil, aquaria in the United Kingdom, Spain, Puerto Rico, Bahamas, and Panama (reviewed by Grutter 2002). Thus, understanding the ecology of gnathiids is important for understanding cleaning behaviour.

Gnathiid larvae are commonly found on fish (e.g. Grutter \& Poulin 1998b and references therein, Heupel \& Bennett 1999, Smit \& Davies 1999, Sikkel et al. 2000, Arnal \& Morand 2001). They are only parasitic as larvae and return to the benthos to digest their blood meal and moult to the next stage (Monod 1926). They have 3 larval stages (Stoll 1962, Wägele 1987). The adults do not feed and reproduce in the benthos (Monod 1926). Although some studies have been done on their ecology (Monod 1926, Amanieu 1963, Upton 1987a,b, Grutter 1998, 
Grutter \& Poulin 1998b, Heupel \& Bennett 1999, Grutter et al. 2000a), little is known about their feeding rates, in particular how long they take to become engorged on fish tissues and how long they remain on the host. However, such information is needed to understand what factors influence the abundance of gnathiids on fish and the impact of cleaner predation on gnathiids.

Monod (1926), in the most detailed study on the ecology of a gnathiid species to date, described the feeding behaviour of Paraganthia formica. Gnathiids attach with their head appendages, the mandibles and gnathopods, around which they pivot easily. They pierce the fish with their maxillules, maxillipeds, and gnathopods and suck blood fluids from the host (Monod 1926). The intestinal reservoir or anterior part of gut, for simplicity called 'gut' in this study, enlarges with blood fluids (see p. 187 in Monod 1926 for the structure of the gut of $P$. formica).

Some limited information is available on the feeding rates of gnathiids, which suggests that they remain on hosts for several hours or days (Stoll 1962, Paperna \& Por 1977, Davies 1981). More information, however, is needed on how gnathiid feeding behaviour varies within a species. The only detailed study to date is that of Smit et al. (2003) on Gnathia africana which showed that the first, second, and third larval stages remain on fish for a mean of 2.3, 2.7 and $10.1 \mathrm{~h}$, respectively.

Gnathiids show similarities to some terrestrial blood feeders, particularly ticks. For example, like argasid soft ticks, they leave the host after feeding to moult (Bush et al. 2001). Gnathiids also have several feeding stages, as do many ticks (Evans 1992). Unlike most ticks, however, some gnathiids are highly mobile (Grutter 1995b).

The ecological and economic importance of terrestrial blood feeders such as ticks, lice, and mosquitoes is well known (Bush et al. 2001). Like many terrestrial blood feeders (Evans 1992, Bush et al. 2001), some gnathiids have been implicated as vectors of the protozoan blood parasite Haemogregarina bigemia (Davies \& Smit 2001). In ticks, the risk of infection of several vector-borne diseases depends on the duration of vector attachment (Piesman et al. 1987, 1991). Understanding how long gnathiids remain on fish and whether this varies, for example among larval stages, may provide insight into the potential risk of infection with blood parasites in fish (Davies \& Smit 2001).

Studies on the Great Barrier Reef (GBR) suggest that gnathiid infestation rates on fish are high. Grutter (1996) found that gnathiid loads on the labrid fish Hemigymnus melapterus on Lizard Island which had been reduced to half their normal load returned to normal $1 \mathrm{~d}$ after manipulation, suggesting that infestation rates were relatively high. Furthermore, Grutter \& Hendrikz (1999) found that $H$. melapterus had twice as many gnathiids at dawn as at sunset on Heron Island (GBR). This implies that fish gained at least $50 \%$ new gnathiids overnight, then lost gnathiids during the day. Most gnathiids on fish were also engorged. Finally, laboratory observations of fish held in containers and exposed to single gnathiids revealed that $75 \%$ of gnathiids became engorged within $4 \mathrm{~h}$ (Grutter \& Hendrikz 1999). These studies suggest that gnathiids feed quickly and that their turnover rate on fish is high. However, the estimates to date have not been precise.

This study was therefore carried out to obtain predictive information on (1) how long gnathiids require to become engorged on fish blood and (2) the period after which they leave the host. Hemigymnus melapterus was used as much is known about its parasites and cleaning interactions with the cleaner fish Labroides dimidiatus (Grutter 1994, 1995b, 1996, 1998, 1999a,b,c, 2001, Grutter \& Hendrikz 1999, Grutter \& Pankhurst 2000, Grutter et al. 2000b, 2002, Grutter \& Lester 2002).

\section{MATERIALS AND METHODS}

Infestation of fish. I used a culture of an undescribed species of Gnathia (Type 1 in Grutter et al. 2000b), identified from the morphology of males obtained through the moulting of larvae, and whose description is currently in progress (N. J. Smit \& A. S. Grutter unpubl. data). To infest fish $(\mathrm{n}=28)$, a single Hemigymnus melapterus (Labridae) was randomly selected from holding tanks and placed in a $1000 \mathrm{l}$ oval tub containing reared gnathiid larvae for 3 min (see Grutter 2001 for diagram of tub and for rearing of parasites). A pilot study showed that the $3 \mathrm{~min}$ exposure to the gnathiid culture was sufficient time for a large number of gnathiids to infest a fish (127) but not long enough for them to become fully engorged (no engorged gut $15 \%$, partly engorged gut $83 \%$, fully engorged pale yellow gut $2 \%, \mathrm{n}=1 \mathrm{fish}$ ). All infestations began between 06:45 and 12:15 h. Fish were then quickly captured with a handnet and transferred from the tub to a white plastic $10 \mathrm{l}$ bucket with a loosely fitted lid where they were held with constant aeration.

All fish were treated prior to using them to ensure that they were gnathiid-free by giving them a freshwater bath (Grutter 1999c, 2001). Fish had been held in captivity since May 13, 1998 and had been used in an earlier study (Grutter 2001). The trials were done between November 21 and 24, 1998. Fish from the earlier study (Grutter 2001) were pooled and those for the present study selected at random from this pool. The mean $( \pm \mathrm{SE})$ length of fish was $13.3( \pm 0.4) \mathrm{cm}$ and the median was $13.6 \mathrm{~cm}$. The minimum and maximum lengths were 9.8 and $17.8 \mathrm{~cm}$, respectively. The length of fish did not differ significantly among time periods (Wilcoxon/Kruskal-Wallis rank sum test: $\chi^{2}=4.86$, $\mathrm{df}=4, \mathrm{p}=0.302)$ and so was not considered further. 
Exposure of gnathiids to fish. Fish were held in buckets for 5, 10, 30, 60, and $240 \mathrm{~min}$; they were then transferred to another bucket for gnathiid removal. A total of 6 fish per exposure time were used, except for times 5 and 10 min where only 5 fish were used. The order of exposure time in the buckets was randomly determined. It should be noted that the above times of exposure do not include the $3 \mathrm{~min}$ that fish were held in tubs to allow infestation with gnathiids.

Parasite counts and gut contents. To determine how many gnathiids had dropped off each fish and how many remained on them at the end of the trials, fish were removed from the buckets (by gently lifting them out of the water with both hands) and placed in a second bucket; the number of gnathiids in the bucket and on the fish (and in the second bucket) were counted. Gnathiids were removed from fish (see Grutter 1999c), recovered from liquids, fixed in $10 \%$ formalin, counted, and measured (see Grutter \& Hendrikz 1999). The presence or absence of a full gut and the proportion (to the nearest $10 \%$ ) of the gut contents that consisted of dark red (rather than clear or opaque to pale yellow, from now on called pale yellow) material was also noted. Due to the large numbers of gnathiids and their high mobility (Grutter 1995b) it was not possible to record the feeding site. Engorged gnathiids with a completely red gut were compared with gnathiids with any pale yellow material and up to $90 \%$ red material in the gut. A subset of gnathiids $(n=200)$ with guts which contained both red and pale yellow material were examined to determine whether the red material was found in the anterior or posterior part of the gut.

Gnathiid larval stages. To determine whether the feeding behaviour of gnathiids varied among the 3 larval stages, gnathiids were separated into stages. Because of the difficulty in separating the larval stages morphologically, particularly given the large numbers involved, each stage was categorized according to its length (not including uropods). The length was determined using a combination of sources measured at $35 \times$ magnification and confirmed by comparing it to the headwidth (an indicator of gnathiid length) (Grutter 1997) of known stages. Source data were (1) the length of gnathiids (with no engorged gut) in the first $(0.69 \mathrm{~mm})$ and second larval stage $(0.84 \mathrm{~mm})$ which had previously been identified using rDNA sequences (species Type 1 in Grutter et al. 2000b), (2) the size of first stage gnathiids reared from wild parents-2 males and 2 females of species Type 1 as above were obtained from Hemigymnus melapterus and larvae produced from each pair (with no engorged gut) had mean widths/lengths $(\mathrm{n}=6)$ of $0.19 / 0.58 \mathrm{~mm}$ and $0.20 / 0.60 \mathrm{~mm}$, respectively-(3) plots of the head width and length of a subset of gnathiids ( $n=173$ ) revealing 3 distinct groups (done separately for gnathi- ids with and without an engorged gut, as the length of gnathiids increases as the gut becomes engorged).

From the above information, gnathiids were categorized into 3 size-classes by their length, representing the 3 larval stages (head width/length). For gnathiids with an engorged gut (praniza larvae), these were: $<0.2 /<0.9 \mathrm{~mm}$ (praniza 1 [P1]), 0.2 to $0.248 / 0.9$ to $1.45 \mathrm{~mm}$ (praniza 2 [P2]), >0.248/>1.45 mm (praniza 3 [P3]). For gnathiids without an engorged gut (zuphea larvae), they were: $<0.2 /<0.7 \mathrm{~mm}$ (zuphea 1), 0.2 to $0.248 / 0.7$ to $1.05 \mathrm{~mm}$ (zuphea 2), >0.248/>1.05 mm (zuphea 3) (as described in Smit et al. 2003). The error (proportion of gnathiids that fit into the head width but not length category), most likely due to variation caused by fixation which occasionally caused curvature or extension of gnathiid bodies, was 7.4, 10.9, and $9.1 \%$ for the above 3 size-classes, respectively. The size-classes agreed with the information from (1) and (2) above, as well as with plots of the gut volume of gnathiids against gnathiid length (see 'Gnathiid gut volumes' and Fig. 1), supporting the assumption that the size-classes, based on the lengths of gnathiids, did indeed represent the 3 larval stages.

Gnathiid gut volumes. Gut volumes of a subset of gnathiids $(n=145)$ were measured to estimate the amount of material held in the gut. The total length (not including the uropods) of gnathiids, and the width and length of the gut were measured. I assumed that the shape of the gut was ellipsoid, as supported by drawings of the gut by Smit et al. (1999), and that the width and thickness of the gut were the same along its length.

Statistical analysis. Because it was not possible to control the number of parasites per fish, the effect of abundance of parasites was examined by considering gnathiid abundance in relation to the variables measured. Separate correlation analyses for each larval stage of the proportion of gnathiids with engorged guts, proportion of gnathiids with a red gut, and proportion of gnathiids that had dropped off fish versus the density of gnathiids were done. All correlations were not significant $(p>0.05)$ and so the effect of density was not considered further.

Mixed model analyses were used to incorporate both random and fixed effects (Bennington \& Thayne 1994). Separate analyses were used to examine the effects of larval stage and time exposed to fish on whether individual gnathiids had an engorged gut, an engorged gut containing red coloured material, or had dropped off the fish after completion of engorgement. Responses were binary and models were fitted using a binomial distribution and logit link. In all models, the fish used in a trial was treated as a random effect and gnathiid larval stage and exposure time were treated as nominal fixed effects.

Models were fitted using Genstat 5.4.1 for Windows (Genstat 5 Committee 1997). The generalized linear 
mixed model (GLMM) procedure was used. When fitting models, a full model was initially fitted with the interaction term. A final model was selected by eliminating nonsignificant $(p>0.25)$ interaction terms. The significance of a term was determined using the Wald statistic for that term when it was the last to be entered in a model (see Genstat 5, Genstat 5 Committee 1997 for rationale).

\section{RESULTS}

A total of 3502 gnathiids infected the 28 fish used. Fish had a mean $( \pm$ SE) $126( \pm 32)$ gnathiids; the median was 75 gnathiids, and the abundance ranged from 7 to 894 gnathiids per fish. An engorged gut was found in $90.8 \%$ of all gnathiids. Of these, $75 \%$ had pale yellow gut contents and $14 \%$ had red gut contents. The remaining $11 \%$ had a combination of pale yellow and red gut contents; $98 \%$ of the subsample had the red material in the anterior part of the gut, with the rest having the red material in the center of the gut and the range for each $10 \%$ increment of red material was 0.35 to $2.36 \%$ of all gnathiids with an engorged gut.

The volume of the gut of gnathiids was correlated with its length $\left(r^{2}=0.957, n=145, p<0.05\right)$ and increased exponentially (Fig. 1). Volumes were estimated with the equation: $\log _{10}$ volume of gnathiid $=-0.7353+4.0152$ $\log _{10}$ total length of gnathiid. On average, P3 larvae had approximately 9 and 20 times larger guts than P2 and P1 larvae, respectively. P1 and P2 larvae did not differ as much in gut volume, with guts of P2 larvae being only approximately 2 times larger than those of P1 larvae.

There was a significant effect of time of exposure $\left(\chi^{2}=\right.$ 449.3, df $=4, \mathrm{p}<0.0001)$ and larval stage $\left(\chi^{2}=20.3, \mathrm{df}=\right.$ $2, \mathrm{p}<0.0001)$ on the likelihood that larvae had an engorged gut. There was no significant interaction be-

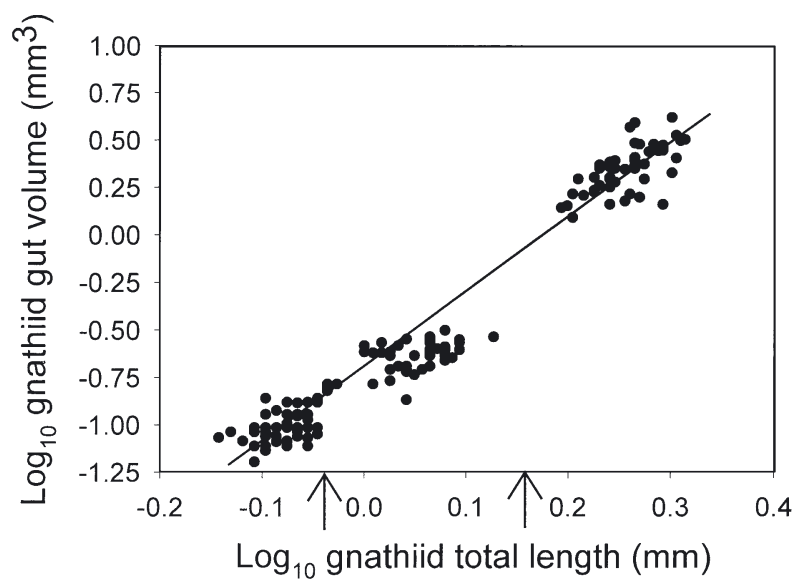

Fig. 1. Gnathia sp. Volume of the gut of gnathiid larvae as a function of length of gnathiid larvae. Data are $\log _{10}$-transformed. Arrows indicate cutoff points determining larval stages used in the analyses tween the effects of time of exposure to fish and larval stages. The likelihood that larvae had an engorged gut increased rapidly over time with P1 and P2 larvae becoming engorged more quickly compared with P3 larvae (Fig. 2). After 30 min, however, most (>93\%) larvae had an engorged gut regardless of their larval stage (Fig. 2).

There was a significant interaction between the effects of time of exposure to fish and larval stage on the likelihood that larvae had red gut contents $\left(\chi^{2}=20.8, \mathrm{df}=8, \mathrm{p}=0.0077\right)$. This was due to the likelihood of P1 and P2 larvae with red gut contents remaining relatively constant over time (1 to $27 \%$ ), while the likelihood of P3 larvae with red gut contents increased rapidly over time (46\% of P3 larvae had red gut contents after $30 \mathrm{~min}$, increasing to $70 \%$ after $60 \mathrm{~min}$ and $86 \%$ after $240 \mathrm{~min}$ ) (Fig. 3).

The likelihood that a larvae would drop off a fish after becoming engorged increased with time. However, the drop-off rate of P3 larvae was slower than that of P1 and P2 larvae $\left(\chi^{2}=42.3, \mathrm{df}=8, \mathrm{p}<0.0001\right)$ (Fig. 4).

\section{DISCUSSION}

\section{Gnathiid engorgement rates}

Gnathiid larvae fed rapidly with most gnathiids becoming engorged after only $30 \mathrm{~min}$ of exposure to fish. The engorgement rate, however, varied among the 3 larval stages of gnathiids. The larger P3 larvae $(>1.45 \mathrm{~mm})$ were slower at becoming engorged than $\mathrm{P} 1(<0.9 \mathrm{~mm})$ and P2 larvae (0.9 to $1.45 \mathrm{~mm})$. This may be due to variation among larval stages in the volume of the gut and diet composition.

The size of the gut of a gnathiid appeared to influence how long it took for it to become engorged. I

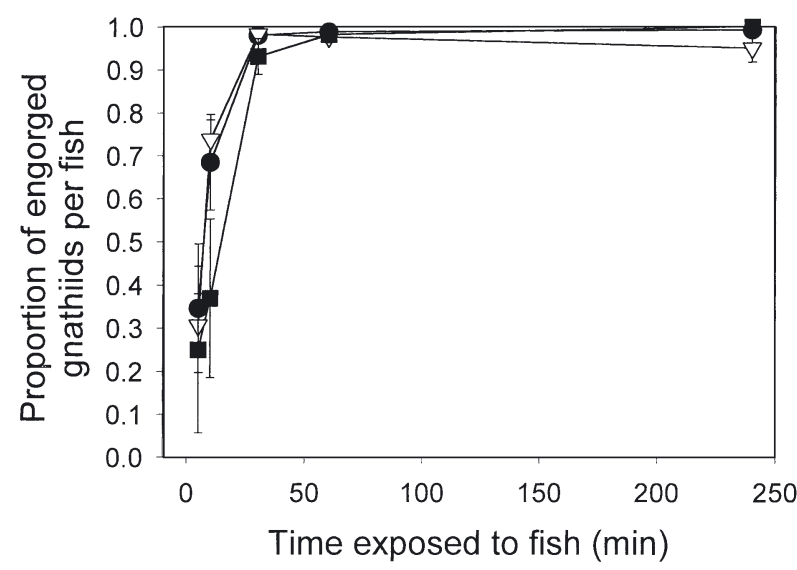

Fig. 2. Gnathia sp. on Hemigymnus melapterus. Mean $( \pm \mathrm{SE})$ proportion of gnathiid larvae with engorged guts per fish for different times of exposure to fish. Larval stages are $(\bullet)$ praniza $1,(\nabla)$ praniza 2 and $(\mathbf{\square})$ praniza 3 


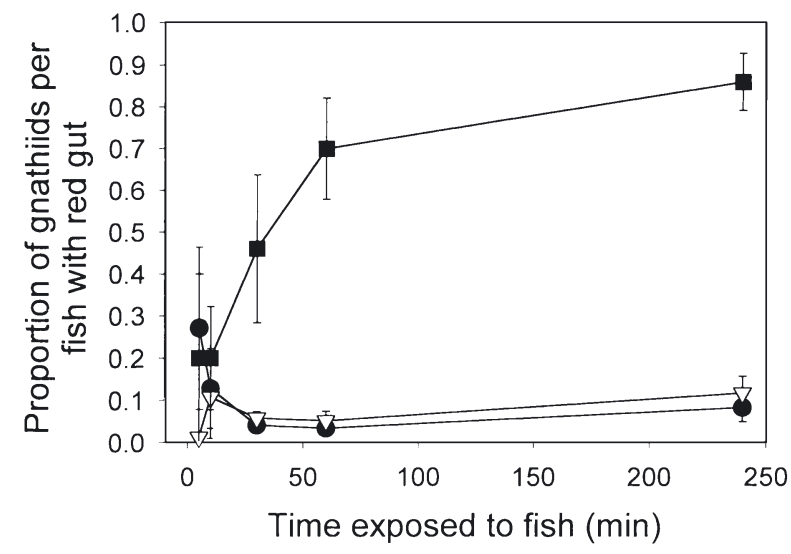

Fig. 3. Gnathia sp. on Hemigymnus melapterus for different times of exposure to fish. The 3 larval stages are shown (symbols as in Fig. 1)

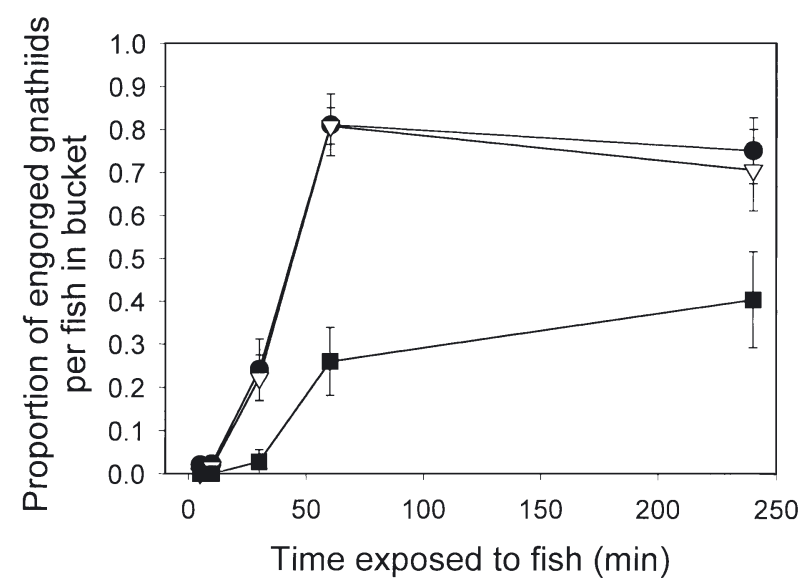

Fig. 4. Gnathia sp. on Hemigymnus melapterus. Mean $( \pm \mathrm{SE})$ proportion of engorged gnathiids larvae per fish which had dropped off the fish at different times of exposure to fish. The 3 larval stages are shown (symbols as in Fig. 1)

found that the gut volume of gnathiids increased exponentially with the size of gnathiids. For example, average sized P3 larvae had 9 to 20 times larger guts than P2 and P1 larvae, respectively. This might explain why P3 larvae required the most time to become engorged.

The relatively larger gut volume of P3 larvae suggests that they remove more host material from their hosts than do smaller gnathiids. The volume of material removed may, however, be larger than the volume of the gut. Other blood feeding arthropods, such as ticks, excrete excess fluid during feeding (Evans 1992). This may occur in gnathiids also, as the material in the gut is not a fluid but rather has the consistency of a thick paste (Monod 1926, pers. obs.), implying that the material in the gut is concentrated. Thus, if the removal of blood is harmful to fish, then larger gnathiids should be more deleterious than smaller ones.
Although the rate at which guts become engorged should decrease with increasing size of the individual, as it does in some ticks (Evans 1992), size alone does not explain the variation in the engorgement rate among the larval stages of gnathiids. For example, the engorgement rates of P1 and P2 larvae were almost identical, despite P2 larvae having guts twice as large as P1 larvae. This suggests that other factors are responsible for this variation in the drop-off rate.

\section{Gnathiid diet}

That the gut contents of P1 and P2 larvae were also similar suggests that the diet, or factors related to it, influences the rate of gut engorgement. P3 larvae mainly had red material in their gut compared with P1 and P2 larvae which had pale yellow with some or no red material in the gut. Little is known about why the colour of gnathiid guts varies. Gnathiids feed on blood and so their diet involves the ingestion of blood plasma and/or the cellular components of blood (Monod 1926). The red colour is most likely from haemoglobin. Material other than blood components may also be ingested, such as lymph and single host cells (Monod 1926). The little evidence available suggests that there are at least 2 causes of the variation in colour of the guts of gnathiids; it is (1) due to variation among host tissues and (2) related to the way in which the blood is ingested (Monod 1926, Smit et al. 2003).

The pale yellow colour in the gut may be largely due to the colour of the plasma of the host. When Thalassoma lunare (Labridae) was exposed in the laboratory to the same species of gnathiid as in this study, gnathiids had red or blue material in the gut (unpubl. data). A blood sample of T. lunare, when centrifuged to separate the blood cells and plasma (following Grutter \& Pankhurst 2000), revealed a blue plasma (unpubl. data). In contrast, the plasma of Hemigymnus melapterus is pale yellow (unpubl. data), as were some of the gut contents of gnathiids from $H$. melapterus. That the differences in the colour of plasma between fishes is reflected in the diet of gnathiids indicates that the material in the gut, when it is not red, is blood plasma.

Monod (1926) proposed that variation in the proportion of red and other coloured material within an individual gnathiid gut is due to the structure of the wound causing blockage in the mouth parts of the parasite. This leads to only plasma filtering through, resulting in a pale yellow gut. With time, however, the wound becomes enlarged allowing blood cells to pass through, resulting in a red gut (Monod 1926). In cases where the 2 colours existed in the same gut, I found that the red material was almost always anterior to the other colour. This implies that the red material was ingested after the other mate- 
rial and agrees with the findings of Monod (1926). Therefore, it may take longer to feed on red than pale yellow material. This may be why P3 larvae, which had mainly red guts, were slower at becoming engorged.

The smaller size of the mouthparts of smaller gnathiids may limit their ability to obtain whole blood with cellular components, because of reduced penetration into the skin or the reduced passage of blood cells. This may explain why mainly P1 and P2 had all or some pale yellow material in their guts, while larger P3 larvae mainly fed on red material. This is supported by observations that pale yellow guts have not been observed in very large gnathiids (>2 mm) (pers. obs.) found on a wide range of teleosts and elasmobranchs (see list in Grutter \& Poulin 1998b). However, gnathiid size alone is not the only explanation for the variation in gut colour, as a few P3 larvae $(14 \%)$ did not have all red guts.

The diet of gnathiids may also vary according to the site of attachment. For example, Gnathia africana feeding on the body of fish have red or mixed-coloured guts, while those on the fins have clear, white or yellow guts (N. J. Smit pers. comm.). In the present study, variation in feeding sites among larval stages was not examined; however, gnathiids have been found on the gills, body, and fins of host fish (pers. obs.).

Variation in the colour of the gut of blood feeders is not uncommon. Engorged ticks with white-coloured guts have occasionally been observed, which were negative for haem (Sutton \& Arthur 1962). Such ticks presumably fed on tissue fluid only (Foggie 1959).

Hemigymnus melapterus is also infested with another species of gnathiid (N. J. Smit \& A. S. Grutter unpubl. data), which usually has a pale yellow gut in all its larval stages. Whether this is a consequence of different feeding habits is unclear. Information on feeding behaviour is needed to provide insight into why the diet composition of gnathiids varies.

\section{Gnathiid drop-off rates}

The number of gnathiids dropping off fish stabilized after $60 \mathrm{~min}$ of exposure to the host. This drop-off rate is faster than that found in other studies of the gnathiid species Paragnathia formica, individuals of which remain on hosts for 'several' hours (Stoll 1962) or 'ingest...blood over a $2 \mathrm{~h}$ to 2 d period' (Upton 1987a); Gnathia piscivora, which (depending on site of attachment) become engorged and leave their host within 2 to $4 \mathrm{~h}$ or for 1 or more days (Paperna \& Por 1977); Gnathia maxillaris, which 'remained attached until replete, feeding taking about 2 to 24 h' (Davies 1981); and Gnathia africana, whose first, second, and third larval stages remain on fish for $2.3,2.7$ and $10.1 \mathrm{~h}$, respectively (Smit et al. 2003).
That some gnathiids remain on fish, even after 30 to 210 min from when they become engorged, may be due to a combination of the mobility of gnathiids and the experimental containers used. Gnathiids are highly mobile (Grutter 1995b). This is supported by observations that many gnathiids visible in the buckets did not appear to be attached securely to the fish as they moved on and off the host (pers. obs.). In addition, after fish were disturbed when removing them from buckets to remove their gnathiids, many of the gnathiids that had been on the fish quickly left the fish when it was placed in a second bucket. After feeding, gnathiids usually seek shelter to digest their meal and moult to the next stage (Monod 1926). Gnathiids would, therefore, have likely attempted to find a shelter after becoming engorged. The bright white walls of the buckets, however, may have repelled some gnathiids, as some species are photophobic (Monod 1926). The lack of shelter for gnathiids in the buckets may thus have led some gnathiids to return to the fish and treat the fish as a shelter.

The rate at which gnathiids left fish varied with the size of the parasite. P1 and P2 larvae dropped off at a similar rate but at a higher rate than large gnathiids. After 30 min of exposure to fish, when most gnathiids were already engorged, 22 and $24 \%$ of P1 and P2 larvae, respectively, had dropped off fish compared with only $3 \%$ of P3 larvae. This difference was maintained after the proportion of gnathiids dropping off fish had plateaued after $60 \mathrm{~min}$.

Where gnathiids feed may also affect how long they remain on the host. Smit et al. (2003) found that gnathiids feeding on the fins remained attached longer than those on the body. The site of attachment of gnathiids in this study was not investigated, as gnathiids were removed immediately after the time period ended to ensure they stopped feeding. A study examining the effect of site attachment on the diet and attachment duration of gnathiids is needed to determine its role in the variation in feeding behaviour observed in this study.

\section{Praniza 3 (P3) larvae feeding behaviour}

That the P1 and P2 larvae engorgement rates, diets, gut volumes, and drop-off rates from fish were very similar to each other but different to that of P3 larvae is of interest. Smit et al. (2003) also found that P1 and P2 larvae remained on fish for similar mean lengths of time, 2.3 and $2.7 \mathrm{~h}$ respectively, while P3 larvae remained on fish almost 5 times longer (10.1 h). P3 larvae may differ from the younger larval stages because they will next moult into adults and so have higher energy requirements. Reproduction in animals is energetically costly. Gnathiid females produce fully developed infective young and males defend harems (Upton 
1987a), both of which are likely energetically demanding. If the red material in guts has a higher energetic content than that of pale yellow material, it may explain why the final third larval stage fed more on this material than the smaller gnathiids. Their larger gut volume would also allow them to store more food. This is the case in ticks, where the ratio of whole blood to extravascular fluid is usually greater during the later stages of the feeding cycle and in older instars (Evans 1992). Egg productivity in some ticks is also dependent on the nutritional status of the female which depends on the amount of blood she has ingested (Balashov 1971). More information is needed on the nutritional value of the red and pale yellow material in the guts of gnathiids.

Although P3 larvae may thus benefit by obtaining more food than smaller larvae, time spent on a fish may also come at a cost. Presumably, the longer time a gnathiid spends on a fish the higher the risk of predation from cleaner fish, which eat large numbers of gnathiids (Grutter 2002).

\section{Abundance of gnathiids per fish}

The mean $( \pm \mathrm{SE})$ abundance of gnathiiids per Hemigymnus melapterus was $126 \pm 32$, which is approximately 6 to 9 times that found on similar sized $H$. melapterus (mean $\pm \mathrm{SE}$ of $13.4 \pm 2.9$ to $21.5 \pm 4.7$ gnathiids per fish) in the wild at Lizard Island (Grutter \& Poulin 1998b). The range of gnathiid abundance per fish was also wide ( 7 to 894). Gnathiid abundance, however, was not correlated with the rate of gut engorgement, the proportion of guts with red material in gut, and the rate at which gnathiids dropped off fish, implying that gnathiid abundance had no significant effect on the patterns observed.

\section{Implications for fish cleaning behaviour}

Larvae of the Gnathia species studied here feed rapidly and then quickly leave the host fish Hemigymnus melapterus. This is supported by the fact that they rapidly leave stressed $H$. melapterus (Grutter 1995b). As gnathiids infest fish at all times of the day and night (Grutter 1999c) and are found on the host at all times of the day (Grutter \& Poulin 1998b, Grutter 1999c, Grutter \& Hendrikz 1999), their rapid movement onto and off the fish implies that the total number of gnathiids infesting fish over a time period is likely to be several times higher than that found per fish at any one point in time. This supports the idea that their turnover rate on fish is relatively high (Grutter 1996), which in turn has important implications for understanding fish cleaning behaviour. Gnathiid larvae are one of the most common parasites eaten by cleaner fishes (see review by Grutter 2002). For example, the cleaner wrasse Labroides dimidiatus eats approximately 1200 gnathiids daily (Grutter 1996); a rapid turnover rate of gnathiids thus provides a steady supply of food. For gnathiids, however, short infestation times may reduce the risk of predation by cleaner fishes (Grutter 2002).

A rapid turnover rate of gnathiids may explain why some fish species seek cleaner wrasse so often. For example, individual barred rabbit fish Siganus doliatus are cleaned by Labroides dimidiatus, on average, 144 times a day, or once every 5 min (Grutter 1995a). By seeking cleaner wrasse repeatedly, 'client' fish have more gnathiids removed than if they sought them only once for a longer period. This is because additional gnathiids, which would have infested fish after the previous visit to a cleaner wrasse, are quickly removed.

The rapid engorgement rate of gnathiids may also explain why some fish species seek cleaner wrasse so often. To minimize the effects of gnathiids on the host, it would be advantageous to remove them quickly, before they remove much blood. As only $30 \%$ of gnathiids had an engorged gut after $5 \mathrm{~min}$ of exposure to fish, a strategy (such as that by Siganus doliatus) of employing visits every 5 min would likely ensure that many gnathiids were removed before they had become fully engorged. Indeed, gnathiids without an engorged gut have been found in the diet of cleaner wrasse (pers. obs.).

Acknowledgements. Many thanks to M. Johnson for assistance in the field and to the staff at Lizard Island Research Station for their support. This work was funded by an Australian Research Council Australian Postdoctoral Fellowship and a University of Queensland External Support Enabling Grant. David Green did the generalized linear mixed-model analyses.

\section{LITERATURE CITED}

Amanieu M (1963) Evolution des populations de Paragnathia formica (Hesse) au cours d'un cycle annuel. Bull Inst Oceanogr 60:1-12

Arnal C, Morand S (2001) Importance of ectoparasites and mucus in cleaning interactions in the Mediterranean Sea. Mar Biol 138:777-784

Arnal C, Côté IM, Sasal P, Morand S (2000) Cleaner-client interactions on a Caribbean reef: influence of correlates of parasitism. Behav Ecol Sociobiol 47:353-358

Balashov YS (1971) Bloodsucking ticks (Ixodoidea) - vectors of diseases of man and animals. In: Eldridge BF (eds) Miscellaneous publications of the Entomological Society of America. Entomological Society of America, College Park, MD, p 163-376

Bansemer C, Grutter AS, Poulin R (2002) Geographic variation in the behaviour of the cleaner fish Labroides dimidiatus (Labridae). Ethology 108:353-366

Bennington CC, Thayne WV (1994) Use and misuse of mixed model analysis of variance in ecological studies. Ecology 75:717-722

Davies AJ (1981) A scanning electron microscope study of the praniza larva of Gnathia maxillaris Montagu (Crustacea, 
Isopoda, Gnathiidae), with special reference to the mouthparts. J Nat Hist 15:545-554

Davies AJ, Smit NJ (2001) The life cycle of Haemogregarina bigemina (Adeleina: Haemogregarinidae) in South African hosts. Folia Parasitol 48:169-177

Evans GO (1992) Principles of acarology. CAB International, Wallingford

Foggie A (1959) Studies on the relationship of tick bite to pyaemia in lambs. Ann Trop Med Parasitol 53:27-34

Genstat 5 Committee (1997) Genstat 5, release 4.1. Command language manual. Numerical Algorithms Group, Oxford

Grutter AS (1994) Spatial and temporal variations of the ectoparasites of seven reef fish species from Lizard Island and Heron Island, Australia. Mar Ecol Prog Ser 115:21-30

Grutter AS (1995a) The relationship between cleaning rates and ectoparasite loads in coral reef fishes. Mar Ecol Prog Ser 118:51-58

Grutter AS (1995b) Comparison of methods for sampling ectoparasites from coral reef fishes. Mar Freshw Res 46:897-903

Grutter AS (1996) Parasite removal rates by the cleaner wrasse Labroides dimidiatus. Mar Ecol Prog Ser 130:61-70

Grutter AS (1997) Size-selective predation by the cleaner fish Labroides dimidiatus. J Fish Biol 50:1303-1308

Grutter AS (1998) Habitat-related differences in the abundance of parasites from a coral reef fish: an indication of the movement patterns of Hemigymnus melapterus. J Fish Biol 53:49-57

Grutter AS (1999a) Cleaner fish really do clean. Nature 398: 672-673

Grutter AS (1999b) Fish cleaning behaviour in Noumea, New Caledonia. Mar Freshw Res 50:209-212

Grutter AS (1999c) Infestation dynamics of parasitic gnathiid isopod juveniles on a coral reef fish Hemigymnus melapterus. Mar Biol 135:545-552

Grutter AS (2001) Parasite infection rather than tactile stimulation is the proximate cause of cleaning behaviour in reef fish. Proc R Soc Lond Ser B Biol Sci 268:1361-1365

Grutter AS (2002) Cleaning behaviour: from the parasite's perspective. Parasitol (Suppl) 124:S65-S81

Grutter AS, Hendrikz J (1999) Diurnal variation in the abundance of parasitic gnathiid isopod larvae on coral reef fish: its implications in cleaning interactions. Coral Reefs 18:187-191

Grutter AS, Lester RJG (2002) Cleaner fish Labroides dimidiatus reduce Argathona macronema (Corallanidae) isopod infections on the coral reef fish Hemigymnus melapterus. Mar Ecol Prog Ser 234:247-255

Grutter AS, Pankhurst NW (2000) The effects of capture, handling, confinement and ectoparasite load on plasma levels of cortisol, glucose and lactate in the coral reef fish Hemigymnus melapterus (Labridae). J Fish Biol 56:391-401

Grutter AS, Poulin R (1998a) Cleaning of coral reef fishes by the wrasse Labroides dimidiatus: influence of client body size and phylogeny. Copeia 1998:120-127

Grutter AS, Poulin R (1998b) Intraspecific and interspecific relationships between host size and the abundance of parasitic larval gnathiid isopods on coral reef fish. Mar Ecol Prog Ser 164:263-271

Grutter AS, Lester RJG, Greenwood J (2000a) Emergence rates from the benthos of the parasitic juveniles of gnathiid isopods. Mar Ecol Prog Ser 207:123-127

Grutter AS, Morgan JAT, Adlard RD (2000b) Characterising parasitic gnathiid isopod species and matching life stages using ribosomal DNA ITS2 sequences. Mar Biol 136:201-205

Grutter AS, McCallum HI, Lester RJG (2002) Optimising cleaning behaviour: minimising the costs and maximising ectoparasite removal. Mar Ecol Prog Ser 234:257-264
Heupel MR, Bennett MB (1999) The occurrence, distribution and pathology associated with gnathiid isopod larvae infecting the epaulette shark, Hemiscyllium ocellatum. Int J Parasitol 29:321-330

Hobson ES (1971) Cleaning symbiosis among California inshore fishes. Fish Bull 69:491-523

Kuwamura T (1976) Different responses of inshore fishes to the cleaning wrasse, Labroides dimidiatus, as observed in Sirahama. Publ Seto Mar Biol Lab 23:119-144

Limbaugh C (1955) Fish life in the kelp beds and the effects of kelp harvesting. University of California Institute of Marine Resources, La Jolla, CA

Losey GS (1972) The ecological importance of cleaning symbiosis. Copeia 1972:820-833

Monod T (1926) Les gnathiidae. Essai monographique (morphologie, biologie, systématique). Mem Soc Sci Nat Maroc 13:1-661

Paperna I, Por FD (1977) Preliminary data on the Gnathiidae (Isopoda) of the Northern Red Sea, the Bitter Lakes and the Eastern Mediterranean and the biology of Gnathia piscivora n. sp. Rapp Comm Int Mer Méditer 24:195-197

Piesman J, Mather TN, Sinsky RJ, Spielman A (1987) Duration of tick attachment and Borrelia burgdorferi transmission. J Clin Microbiol 25:557-558

Piesman J, Maupin GO, Campos EG, Happ CM (1991) Duration of adult female Ixodes dammini attachment and transmission of Borrelia burgdorferi, with description of a needle aspiration isolation method. J Infect Dis 163:895-897

Randall JE (1958) A review of the labrid fish genus Labroides, with description of two new species and notes on ecology. Pac Sci 12:327-347

Sikkel PC, Fuller CA, Hunte W (2000) Habitat/sex differences in time at cleaning stations and ectoparasite loads in a Caribbean reef fish. Mar Ecol Prog Ser 193:191-199

Smit NJ, Davies AJ (1999) New host records for Haemogregarina bigemina Laveran \& Mesnil, 1901 (Apicomplexa; Adeleina) from South Africa. J Mar Biol Assoc UK 79: 933-935

Smit NJ, Van As JG, Basson L (1999) A redescription of the adult male and larvae of Gnathia africana Barnard, 1914 (Gnathiidae: Crustacea: Isopoda) from southern Africa. Folia Parasitol 46:229-240

Smit NJ, Basson L, Van As JG (2003) Life cycle of the temporary fish parasite, Gnathia africana (Crustacea: Isopoda). Folia Parasitol 50:135-142

Stoll C (1962) Cycle évolutif de Paragnathia formica (Hesse) (Isopode - Gnathiidae). Cah Biol Mar 3:401-416

Sutton E, Arthur DR (1962) Tick feeding in relations to disease transmission. In: Arthur DR (ed) Aspects of disease transmission by ticks, Vol 6. Symp Zool Soc Lond, Zoological Society of London, London, p 223-253

Upton NPD (1987a) Asynchronous male and female life cycles in the sexually dimorphic, harem-forming isopod Paragnathia formica (Crustacea: Isopoda). J Zool 212:677-690

Upton NPD (1987b) Gregarious larval settlement within a restricted intertidal zone and sex differences in subsequent mortality in the polygynous saltmarsh isopod Paragnathia formica (Crustacea: Isopoda). J Mar Biol Assoc UK 67:663-678

Wägele JW (1987) Description of the postembryonal stages of the Antarctic fish parasite Gnathia calva Vanhoffen (Crustacea: Isopoda) and synonymy with Heterognathia Amar \& Roman. Polar Biol 7:77-92

Wicksten MK (1998) Behaviour of cleaners and their client fishes at Bonaire, Netherlands Antilles. J Nat Hist 32: 13-30

Submitted: May 30, 2002; Accepted: March 12, 2003

Proofs received from author(s): September 3, 2003 